\title{
EFFICIENCY OF SALES OF EDIBLE EGGS BY WEIGHT AND CATEGORIES. PRICING METHODOLOGY
}

\author{
Alexey Kavtarashvili, ${ }^{1, *}$ \\ ${ }^{1}$ Laboratory of the Technology of Egg Production, Federal Scientific Center «All-Russian Research and Technological Institute of \\ Poultry" of Russian Academy of Sciences, Sergiev Posad, Russia
}

\begin{abstract}
The yields of eggs of various categories from modern highly productive crosses of chickens (SP789, Lohmann LSL Classic, Lohmann Brown Lite) were studied. The comparative efficiency of the egg sale by weight and categories, the development of a pricing methodology are discussed. It was found that for the considered crosses the first category is the modal class or the class of the highest frequency of occurrence. The average weight, the cost of $1 \mathrm{~g}$ of egg weight, and the new selling price of eggs of the first category practically coincide with the average values of these parameters of the general set. The most economically feasible is the sale of edible eggs by weight. However, it requires additional financial investments for the purchase, installation, and maintenance of weighing equipment. In this regard, the author has developed and proposed a methodology for determining the single-piece price sale of eggs of different categories, which makes it possible to increase the income of an enterprise as compared to selling eggs by weight. According to the new methodology the selling price of the first category eggs is taken as a basis for assessing the selling price of eggs of other categories. This value is multiplied by the coefficients for the corresponding categories, which are calculated by dividing the new price of eggs of each category by the new price of eggs of the first category. These coefficients should be developed for each specific cross, taking into account the duration of the productive seasons and the conditions of the farms.
\end{abstract}

\section{Introduction}

In modern economic conditions increasing the efficiency of production in poultry farming becomes not only the main direction of its development but also practically the only opportunity to further increase the production of eggs and poultry meat, and to increase the competitiveness and profitability of the industry [1-4]. The efficiency of the productive activity of poultry farms depends on a set of interrelated factors: housing conditions, productivity, livability and duration of productive use of poultry, product quality, feed and labor costs for production, market prices of products [5-12].

Currently, poultry farms in Russia and the CIS countries sell edible eggs to the consumer by item, taking into account weight categories [13] while in the EU countries edible eggs are sold by weight [14].

According to the Russian State Standard GOST 31654 - 2012 "Edible chicken eggs. Speci-fications" [15], edible eggs are divided into 5 weight categories: the third (35-44.9 g), the second (45-54.9 g), the first (55-64.9), selected (65-74.9 g), and the highest (75 g and more). The disad-vantage of this standard is that each weight category of eggs has a fairly large interval $(9.9 \mathrm{~g})$ [16]. So, when eggs are sold by the categorized items, the selling price of the lightest and the heaviest eggs within each category and the resulting income of the farm will be the same.
Analysis of the work of poultry enterprises in Russia showed that there is no single meth-odology for determining the selling price of eggs of various categories, and this process is arbi-trary. For example, during the period of studies the selling price of 10 eggs of the third, second, first, selected and highest categories amounted to 24.7, 27.3, 38.8, 45.7 and 52.6 rubles (SP1) at the Selection and Genetic Center "Zagorskoe Experimental Breeding Farm" of the Moscow re-gion. These selling prices at the Mendeleevskaya poultry farm in the Perm Territory were 20.0, 29.1, 35.4, 38.2, and 41.5 rubles (SP2); and 29.0, 31.0, 37.0, 38.0 and 39.0 rubles (SP3) at the Druzhba poultry farm in the Krasnodar Territory.

The purpose of this work was to study the yields of eggs of different categories for some modern highly productive crosses of chickens, to compare the efficiency of egg selling by weight and categories, and to develop a unified pricing methodology.

\section{Materials and methods}

The studies were carried out at the Selection and Genetic Center "Zagorskoe Experimental Breeding Farm" of the Federal Scientific Center "All-Russian Research and Technological Insti-tute of Poultry" of Russian Academy of Sciences (SGC ARRTPI) of the Moscow region and the poultry farm Mendeleevskaya of the Perm Territory.

\footnotetext{
* Corresponding author: alexk@,vnitip.ru
} 
Table 1. Weight and yield of eggs by category.

\begin{tabular}{|c|c|c|c|c|c|c|c|c|c|c|c|c|}
\hline \multirow{3}{*}{$\begin{array}{c}\text { Egg } \\
\text { categories }\end{array}$} & \multicolumn{4}{|c|}{ SP-789 cross } & \multicolumn{4}{|c|}{ Lohmann LSL Classic cross } & \multicolumn{4}{|c|}{ Lohmann Brown Lite cross } \\
\hline & \multicolumn{2}{|c|}{$\begin{array}{c}\text { Number of } \\
\text { eggs }\end{array}$} & \multicolumn{2}{|c|}{ Mass of eggs, $g$} & \multicolumn{2}{|c|}{$\begin{array}{c}\text { Number of } \\
\text { eggs }\end{array}$} & \multicolumn{2}{|c|}{ Mass of eggs, $g$} & \multicolumn{2}{|c|}{$\begin{array}{c}\text { Number of } \\
\text { eggs }\end{array}$} & \multicolumn{2}{|c|}{ Mass of eggs, $g$} \\
\hline & pcs. & $\%$ & total & average & pcs. & $\%$ & total & average & pcs. & $\%$ & total & average \\
\hline Third & 11 & 0.79 & 478 & 43.46 & 4 & 0.28 & 173 & 43.23 & 46 & 3.18 & 1915 & 41.63 \\
\hline Second & 319 & 22.84 & 16338 & 51.22 & 252 & 17.52 & 13204 & 52.40 & 145 & 10.03 & 7409 & 51.10 \\
\hline First & 806 & 57.69 & 48127 & 59.71 & 913 & 63.49 & 54600 & $\mathbf{5 9 . 8 0}$ & 871 & 60.24 & 52802 & 60.62 \\
\hline Selected & 248 & 17.75 & 16867 & 68.01 & 257 & 17.87 & 17475 & 68.00 & 373 & 25.79 & 25398 & 68.09 \\
\hline Highest & 13 & 0.93 & 1037 & 79.77 & 12 & 0.84 & 929 & 77.43 & 11 & 0.76 & 923 & 83.91 \\
\hline $\begin{array}{l}\text { Total and } \\
\text { in average }\end{array}$ & $\begin{array}{c}139 \\
7\end{array}$ & 100 & 82840 & 59.30 & 1438 & 100 & 86381 & 60.07 & 1446 & 100 & 88447 & 61.17 \\
\hline
\end{tabular}

1397 eggs from chickens of the productive flocks of cross SP-789 (SGC ARRTPI) and 1438 and 1446 eggs from crosses Lohmann LSL Classic and Lohmann Brown Lite (Mende-leevskaya), respectively, were weighed individually monthly (three days in a row) during their productive period. The laboratory scales with an accuracy of $0.1 \mathrm{~g}$ were used. The total and average weights of eggs; the yields of eggs of the highest, selected, first, second, third categories [15]; the total and average weights of eggs by category were determined.

\section{Results and discussion}

During the productive period the yields of eggs of the third, second, first selected and highest categories were as follows:

- $0.79,22.84,57.69,17.75$, and $0.93 \%$, respectively, for the SP-789 cross with an average egg weight of
43.46, 51.22, 59.71, 68.01, $79.77 \mathrm{~g}$;

- $0.28,17.52,63.49,17.87$, and $0.84 \%$ for the Lohmann LSL Classic with an average egg weight of 43.23, 52.40, 59.80, 68.00, $77.43 \mathrm{~g}$;

- 3.18, 10.03, 60.24, 25.79, and $0.76 \%$ for the Lohmann Brown Lite with an average egg weight of $41.63,51.10,60.62,68.09,83.91 \mathrm{~g}$, respectively.

The total and average weights of all weighed eggs were 82,840 and $59.30 \mathrm{~g}$ for the SP-789 cross, 86,381 and $60.07 \mathrm{~g}$ for the Lohmann LSL Classic, 88,447 and $61.17 \mathrm{~g}$ for the Lohmann Brown Lite (Table 1).

Taking into account the listed characteristics and the selling prices for eggs categories, mathematical calculations were performed to determine the comparative efficiency of selling the edible eggs by weight and by category (by item). The following parameters were calculated:

- The cost of $1 \mathrm{~g}$ of egg weight - by dividing the

Table 2. Prices when selling eggs by category according to SP1 prices and by weight.

\begin{tabular}{|c|c|c|c|c|c|}
\hline \multirow{2}{*}{ Egg categories } & \multicolumn{2}{|c|}{ Sales of eggs by category } & \multicolumn{2}{|c|}{ Sales of eggs by weight } & \multirow[b]{2}{*}{$\begin{array}{l}\text { The cost of } 1 \text { egg } \\
\text { for the cost of } 1 \mathrm{~g} \\
\text { of egg mass of the } \\
\text { 1st category, rubles } \\
\text { (new price) }\end{array}$} \\
\hline & $\begin{array}{l}\text { Selling price } \\
\text { of } 1 \text { egg, rub. }\end{array}$ & $\begin{array}{c}\text { Income, } \\
\text { rubles }\end{array}$ & $\begin{array}{r}\text { Cost of } 1 \mathrm{~g} \\
\text { of egg mass, } \\
\text { rub. }\end{array}$ & $\begin{array}{l}\text { Income based on the } \\
\text { price of } 1 \mathrm{~g} \text { of egg } \\
\text { mass of the } 1 \mathrm{st} \\
\text { category, rub. }\end{array}$ & \\
\hline \multicolumn{6}{|c|}{ SP-789 cross } \\
\hline Third & 2.47 & 27.2 & 0.057 & 31 & 2.82 \\
\hline Second & 2.73 & 871 & 0.053 & 1062 & 3.33 \\
\hline First & 3.88 & 3127 & 0.065 & 3128 & 3.88 \\
\hline Selected & 4.57 & 1133 & 0.067 & 1096 & 4.42 \\
\hline Highest & 5.26 & 68 & 0.066 & 67 & 5.19 \\
\hline Total and in average & 3.74 & 5226 & 0.063 & 5384 & 3.85 \\
\hline \multicolumn{6}{|c|}{ Lohmann LSL Classic cross } \\
\hline Third & 2.47 & 10 & 0.057 & 11 & 2.81 \\
\hline Second & 2.73 & 688 & 0.052 & 858 & 3.41 \\
\hline First & 3.88 & 3542 & 0.065 & 3549 & 3.89 \\
\hline Selected & 4.57 & 1174 & 0.067 & 1136 & 4.42 \\
\hline Highest & 5.26 & 63 & 0.068 & 60 & 5.03 \\
\hline Total and in average & 3.81 & 5477 & 0.063 & 5614 & 3.90 \\
\hline \multicolumn{6}{|c|}{ Lohmann Brown Lite cross } \\
\hline Third & 2.47 & 114 & 0.059 & 123 & 2.66 \\
\hline Second & 2.73 & 396 & 0.054 & 474 & 3.27 \\
\hline First & 3.88 & 3379 & 0.064 & 3379 & 3.88 \\
\hline Selected & 4.57 & 1705 & 0.067 & 1625 & 4.36 \\
\hline Highest & 5.26 & 58 & 0.063 & 59 & 5.37 \\
\hline Total and in average & 3.91 & 5652 & 0.064 & 5660 & 3.91 \\
\hline
\end{tabular}


Table 3. Prices when selling eggs by category according to SP2 prices and by weight.

\begin{tabular}{|c|c|c|c|c|c|}
\hline \multirow[t]{2}{*}{ Egg categories } & \multicolumn{2}{|c|}{ Sales of eggs by category } & \multicolumn{2}{|c|}{ Sales of eggs by weight } & \multirow{2}{*}{$\begin{array}{l}\text { The cost of } 1 \text { egg for } \\
\text { the cost of } 1 \mathrm{~g} \text { of egg } \\
\text { mass of the } 1 \mathrm{st} \\
\text { category, rubles (new } \\
\text { price) }\end{array}$} \\
\hline & $\begin{array}{l}\text { Selling price } \\
\text { of } 1 \text { egg, rub. }\end{array}$ & $\begin{array}{c}\text { Income, } \\
\text { rubles }\end{array}$ & $\begin{array}{l}\text { Cost of } 1 \mathrm{~g} \\
\text { of egg } \\
\text { mass, rub. }\end{array}$ & $\begin{array}{l}\text { Income based on the price of } \\
1 \mathrm{~g} \text { of egg mass of the } 1 \mathrm{st} \\
\text { category, rub. }\end{array}$ & \\
\hline \multicolumn{6}{|c|}{ SP-789 cross } \\
\hline Third & 2.00 & 22 & 0.046 & 28 & 2.56 \\
\hline Second & 2.91 & 928 & 0.057 & 964 & 3.02 \\
\hline First & 3.54 & 2853 & 0.059 & 2839 & 3.52 \\
\hline Selected & 3.82 & 947 & 0.056 & 995 & 4.01 \\
\hline Highest & 4.15 & 54 & 0.052 & 61 & 4.71 \\
\hline Total and in average & 3.44 & 4804 & 0.058 & 4887 & 3.50 \\
\hline \multicolumn{6}{|c|}{ Lohmann LSL Classic cross } \\
\hline Third & 2.00 & 8 & 0.046 & 10 & 2.55 \\
\hline Second & 2.91 & 733 & 0.056 & 779 & 3.09 \\
\hline First & 3.54 & 3232 & 0.059 & 3221 & $\mathbf{3 . 5 3}$ \\
\hline Selected & 3.82 & 982 & 0.056 & 1031 & 4.01 \\
\hline Highest & 4.15 & 50 & 0.054 & 55 & 4.57 \\
\hline Total and in average & 3.48 & 5005 & 0.058 & 5096 & 3.54 \\
\hline \multicolumn{6}{|c|}{ Lohmann Brown Lite cross } \\
\hline Third & 2.00 & 92 & 0.048 & 111 & 2.41 \\
\hline Second & 2.91 & 422 & 0.057 & 430 & 2.96 \\
\hline First & 3.54 & 3083 & 0.058 & 3063 & 3.52 \\
\hline Selected & 3.82 & 1425 & 0.056 & 1473 & 3.95 \\
\hline Highest & 4.15 & 46 & 0.050 & 54 & 4.87 \\
\hline Total and in average & 3.51 & 5068 & 0.058 & 5131 & 3.55 \\
\hline
\end{tabular}

selling price of 1 egg by the average weight of eggs in each category;

- Income from the sale of eggs by weight - by multiplying the cost of $1 \mathrm{~g}$ of egg weight of the first category by the total weight of eggs in each category;

- A new selling price for eggs of different categories - by multiplying the cost of $1 \mathrm{~g}$ of egg weight of the first category by the average weight of eggs in each category.

It was found that when selling eggs by categories according to SP1 (Table 2), the SP-789 cross got a total income of 5226 rubles, while when selling eggs by weight, based on the cost of $1 \mathrm{~g}$ of egg mass of the $1 \mathrm{st}$ category ( 0.065 rubles) it amounted to 5384 rubles. For the Lohmann LSL Classic cross, the total income from the sale of eggs by category was 5,477 rubles, and from the sale of eggs by weight, based on the cost of $1 \mathrm{~g}$ of egg mass of the 1 st category ( 0.065 rubles) it was 5,614 rubles. For the Lohmann Brown Lite cross, the total income from the sale of eggs by category amounted to 5652 rubles, and from the sale of eggs by weight, based on the cost of $1 \mathrm{~g}$ of egg mass of the 1 st category $(0.064$ rubles) it was 5660 rubles.

When selling eggs by categories according to SP2 (Table 3), the total income of the SP-789 cross was 4804 rubles, while when selling eggs by weight, based on the cost of $1 \mathrm{~g}$ of egg mass of the 1 st category ( 0.059 rubles) it amountsed to 4887 rubles. For the Lohmann LSL Classic cross, the total income from the sale of eggs by category was 5005 rubles, and from the sale of eggs by weight, it was 5096 rubles. For the Lohmann Brown Lite cross, the total income from the sale of eggs by category amounted to 5068 rubles, and from the sale of eggs by weight, based on the cost of $1 \mathrm{~g}$ of egg mass of the $1 \mathrm{st}$ category ( 0.058 rubles) it was 5131 rubles.

Similarly, when selling eggs by categories according to SP3 (Table 4), the total income of the SP-789 cross was 4996 rubles, and when selling eggs by weight, based on the cost of $1 \mathrm{~g}$ of egg mass of the 1 st category $(0.062$ rubles) it was 5137 rubles. For the Lohmann LSL Classic cross total income from the sale of eggs by category was 5195 rubles, and when selling eggs by weight, based on the cost of $1 \mathrm{~g}$ of egg mass of the 1st category $(0.062$ rubles) it was 5361 ru-bles. For the Lohmann Brown Lite cross, the total income from the sale of eggs by category amounted to 5266 rubles, and from the sale of eggs by weight, based on the cost of $1 \mathrm{~g}$ of egg mass of the $1 \mathrm{st}$ category (0.061 rubles) it was 5394 rubles.

The presented data show that it is most economically feasible to sell edible eggs by weight. When selling eggs by weight based on the cost of $1 \mathrm{~g}$ of egg weight of the 1 st category in comparison with selling by categories (by item) according to the prices SP1, SP2, and SP3 for SP789, Lohmann LSL Classic, and Lohmann Brown Lite, the additional income was 158, 137 and 8; 83, 91 and 63; 141,166 and 128 rubles. Per 10 eggs it is $1.13,0.95$ and $0.06 ; 0.60,0.63$, and $0.44 ; 1.01,1.15$, and 0.89 rubles, which in the scale of a poultry farm of average capacity producing 155 million eggs per year will provide additional income of $17.52,14.73$, and $0.93 ; 9.30,9.77$, and $6.82 ; 15.66,17.83$, and 13.80 million rubles per year, respectively.

So, the data in Tables 2, 3, and 4 indicate that when selling edible eggs by weight, compared to selling by categories (by item), income from the SP-789, Lohmann LSL Classic, and Lohmann Brown Lite crosses rises by 
Table 4. Prices when selling eggs by category according to SP3 prices and by weight.

\begin{tabular}{|c|c|c|c|c|c|}
\hline \multirow[t]{2}{*}{ Egg categories } & \multicolumn{2}{|c|}{$\begin{array}{l}\text { Sales of eggs by } \\
\text { category }\end{array}$} & \multicolumn{2}{|c|}{ Sales of eggs by weight } & \multirow{2}{*}{$\begin{array}{l}\text { The cost of } 1 \text { egg for the } \\
\text { cost of } 1 \mathrm{~g} \text { of egg mass } \\
\text { of the } 1 \text { st category, } \\
\text { rubles (new price) }\end{array}$} \\
\hline & $\begin{array}{l}\text { Selling } \\
\text { price of } 1 \\
\text { egg, rub. }\end{array}$ & $\begin{array}{c}\text { Income, } \\
\text { rubles }\end{array}$ & $\begin{array}{l}\text { Cost of } 1 \mathrm{~g} \\
\text { of egg } \\
\text { mass, rub. }\end{array}$ & $\begin{array}{l}\text { Income based on the } \\
\text { price of } 1 \mathrm{~g} \text { of egg mass } \\
\text { of the } 1 \text { st category, rub. }\end{array}$ & \\
\hline \multicolumn{6}{|c|}{ SP-789 cross } \\
\hline Third & 2.90 & 32 & 0.067 & 30 & 2.70 \\
\hline Second & 3.10 & 989 & 0.061 & 1013 & 3.18 \\
\hline First & 3.70 & 2982 & 0.062 & 2984 & 3.70 \\
\hline Selected & 3.80 & 942 & 0.056 & 1046 & 4.22 \\
\hline Highest & 3.90 & 51 & 0.049 & 64 & 4.95 \\
\hline Total and in average & 3.58 & 4996 & 0,061 & 5137 & 3.68 \\
\hline \multicolumn{6}{|c|}{ Lohmann LSL Classic cross } \\
\hline Third & 2.90 & 12 & 0.067 & 11 & 2.68 \\
\hline Second & 3.10 & 781 & 0.059 & 819 & 3.25 \\
\hline First & 3.70 & 3378 & 0.062 & 3385 & 3.71 \\
\hline Selected & 3.80 & 977 & 0.056 & 1084 & 4.22 \\
\hline Highest & 3.90 & 47 & 0.050 & 62 & 4.80 \\
\hline Total and in average & 3.61 & 5195 & 0.061 & 5361 & 3.73 \\
\hline \multicolumn{6}{|c|}{ Lohmann Brown Lite cross } \\
\hline Third & 2.90 & 133 & 0.070 & 117 & 2.54 \\
\hline Second & 3.10 & 450 & 0.061 & 452 & 3.12 \\
\hline First & 3.70 & 3223 & 0.061 & 3221 & 3.70 \\
\hline Selected & 3.80 & 1417 & 0.056 & 1549 & 4.15 \\
\hline Highest & 3.90 & 43 & 0.047 & 56 & 5.12 \\
\hline Total and in average & 3.64 & 5266 & 0.060 & 5394 & 3.73 \\
\hline
\end{tabular}

Table 5. Coefficients for determining the selling price of eggs of various categories.

\begin{tabular}{|c|c|c|c|c|c|c|c|c|c|c|c|c|}
\hline \multirow[b]{2}{*}{$\begin{array}{c}\text { Egg } \\
\text { categories }\end{array}$} & \multicolumn{4}{|c|}{ SP-789 cross } & \multicolumn{4}{|c|}{ Lohmann LSL Classic cross } & \multicolumn{4}{|c|}{ Lohmann Brown Lite } \\
\hline & SP1 & SP2 & SP3 & $\begin{array}{c}\text { In } \\
\text { avera } \\
\text { ge }\end{array}$ & SP1 & SP2 & SP3 & $\begin{array}{c}\text { In } \\
\text { average }\end{array}$ & SP1 & SP2 & SP3 & $\begin{array}{c}\text { In } \\
\text { aver } \\
\text { age }\end{array}$ \\
\hline Third & 0.727 & 0.727 & 0.730 & 0.729 & 0.722 & 0.722 & 0.722 & 0.722 & 0.686 & 0.685 & 0.687 & $\begin{array}{c}0.68 \\
6 \\
\end{array}$ \\
\hline Second & 0.858 & 0.858 & 0.860 & 0.859 & 0.877 & 0.875 & 0.876 & 0.876 & 0.843 & 0.841 & 0.843 & $\begin{array}{c}0.84 \\
2\end{array}$ \\
\hline First & 1 & 1 & 1 & 1 & 1 & 1 & 1 & 1 & 1 & 1 & 1 & 1 \\
\hline Selected & 1.139 & 1.139 & 1.141 & 1.140 & 1.136 & 1.136 & 1.138 & 1.137 & 1.124 & 1.122 & 1.122 & $\begin{array}{c}1.12 \\
3\end{array}$ \\
\hline Highest & 1.338 & 1.338 & 1.338 & 1.338 & 1.293 & 1.295 & 1.294 & 1.294 & 1.384 & 1.384 & 1.384 & $\begin{array}{c}1.38 \\
4\end{array}$ \\
\hline
\end{tabular}

$3.02,2.50$ and $0.14 \%$ for SP1 prices; by $1.73,1.82$ and $1.24 \%$ for SP2 prices, and by $2.82,3.20$, and $2.43 \%$ for SP3 prices.

As a result of the study, it was found that for all three crosses, the modal class or the class of the highest frequency of occurrence is the first category (57.69$63.49 \%$ ). The average weight of eggs, the cost of $1 \mathrm{~g}$ of egg weight and the new selling price of eggs of this category practically coincides with the average values of the general set.

It should be noted that the sale of eggs by weight requires additional financial investments for the purchase, installation and maintenance of weighing equipment. In this regard, in order to minimize financial losses of enterprises when selling eggs, coefficients have been developed (Table 5) to determine the selling price of eggs of different categories for the studied crosses. They are calculated by dividing the new price of eggs in each category by the new price of eggs in the first category (see tables 2, 3 and 4).
Coefficients for determining the selling price of eggs of different categories should be developed for each specific cross, taking into account the duration of the operation of chickens and the conditions of the farms. According to the new methodology, the selling price of eggs of the first category is taken as the basis for determining the selling price of eggs of different categories, and this indicator is multiplied by the coefficients for the corresponding categories.

Example: if the estimated selling price of 10 eggs of the first category is 42 rubles, then for the SP-789 cross the selling price of 10 eggs of the third, second, selected and highest categories will be 30.62 (42 rubles x 0.729 ), 36.08 (42 x 0.859), $47.88(42 \times 1.140)$ and $56.20(42 \times$ 1.338) rubles. For the Lohmann LSL Classic cross the prices will be 30.32 (42 x 0.722), 36.79 (42 x 0.876), $47.75(42 \times 1.137)$, and $54.35(42 \times 1.294)$ rubles. For the Lohmann Brown Lite cross the prices will be 28.81 $(42 \times 0.686), 35.36(42 \times 0.842), 47.17$ (42 x 1.123), and $58.13(42 \times 1.384)$ rubles, respectively. 


\section{Conclusion}

The study showed that for all the considered crosses the modal class or the class of the highest frequency of occurrence is the first category $(57.69-63.49 \%)$. The average weight of eggs, the cost of $1 \mathrm{~g}$ of egg weight and the new selling price of eggs of this category practically coincide with the average values of these parameters of the general set. It was found that it is most economically reasonable to sell edible eggs by weight. The developed methodology for de-termining the selling price of eggs of different categories makes it possible to increase the income of enterprises to the level of income when selling eggs by weight.

\section{References}

1. E. Altahat, Factors affecting profitability of layer hens enterprises, American Journal of Agricultural and Biological Sciences, 7(1), 106-113 (2012).

2. J.A. Mench, D.A. Sumner, J.T. Rosen-Molina, Sustainability of egg production in the United States - The policy and market context, Poultry Science, 90, 229-240 (2011).

3. M. Vaarst, S. Steenfeldt, K. Horsted, Sustainable development perspectives of poultry production, World's Poultry Science Journal, 71(4), 609-620 (2015).

4. A.K. Thiruvenkadan, R. Prabakaran, recent approaches in poultry breeding, Appro. Poult. Dairy \& Vet. Sci., 2(2), 124-132 (2017).

5. M. Shklyar, N. Chuprina, Factors determining both dynamic development and economic growth of industrial poultry farming, Pticefabrika, 2, 4-7 (2011).

6. V.I. Fisinin, A. Sh. Kavtarashvili, Heat Stress in Poultry. Report I. Danger, physiolog-ical changes in the body, signs and manifestations (review), Sel'skokhozyaystvennaya biologiya, 50(2), 162-171 (2015).

7. H.A. Elson, Poultry welfare in intensive and extensive production systems, World's Poultry Science Journal, 71(3): 449-460 (2015).

8. M.M. Bain, Y. Nys, I.C. Dunn, Increasing persistency in lay and stabilising egg quality in longer laying cycles. What are the challenges? British Poultry Science, 57(3), 330-338 (2016).

9. A.L. Shtele, Problem of egg productivity in hens and its early prediction, sel'skokhozyaistvennaya biologiya [Agricultural biology], 6, 26-35 (2014).

10. A.Sh. Kavtarashvili, I.L. Stefanov, V.S. Svitkin, E.N. Novotorov. Development of rec-ipes for diets to effectively and safely increase the functional value of chicken eggs (Gallus gallus L.), Agricultural biology, 53 (4), 787-798 (2018).

11. A. Carlson, E. Jaenicke, Changes in retail organic price premiums from 2004 to 2010; United States Department of Agriculture: Washington, DC, USA, 38 (2016).
12. C. U. Mere, P.I. Ater, J.A.C. Ezihe, Analysis of profitability and constraints of table egg production enterprises in Benue State, Nigeria, International Journal of Environment, Agri-culture and Biotechnology, 2(6), 2936-2944 (2017).

13. A.L. Shtelle, Development of Specifications for a National Standard for Edible Chick-en Eggs, Poultry and Poultry Products, 3, 53-56 (2014).

14. L. Christopher, EU to ban selling eggs by the dozen: Shopkeepers' fury as they are told all food must be weighed and sold by the kilo, Daily Mail, UK, 27.06. (2010).

15. Interstate standard GOST 31654-2012 "Edible chicken eggs. Specifications", Moscow, Standartinform, 8 (2013).

16. V.V. Gushchin, Comparative analysis of regulatory documents for edible chicken eggs of the countries of the Customs Union, Ukraine and the European Union, Poultry and Poultry Products, 1, 22-25 (2012). 